\title{
PENGARUH URINE KAMBING DAN MEDIA TANAM TERHADAP PERTUMBUHAN STEK BATANG JAMBU AIR DELI HIJAU (Syzygium aqueum Merr.)
}

\section{EFFECT OF GOAT URINE AND PLANTING MEDIUM TO STEM CUTTINGS GROWTH OF ROSE WATER APPLE (Syzygium aqueum Merr.) cV. GREEN DELI}

\author{
Tian Agustiawan ${ }^{1}$, Adam Saepudin ${ }^{1}$, Dedi Natawijaya ${ }^{1}$ \\ ${ }^{1}$ Program Studi Agroteknologi Fakultas Pertanian Universitas Siliwangi \\ Jalan Siliwangi No. 24 Kota Tasikmalaya Kode Pos 46115 Jawa Barat \\ Korespondensi : adamsaepudin@unsil.ac.id
}

\begin{abstract}
ABSTRAK
Permasalahan yang sering dihadapi dalam perbanyakan jambu air Deli Hijau melalui stek batang adalah perakaran yang sulit tumbuh. Salah satu upaya yang dapat dilakukan adalah dengan pemberian zat pengatur tumbuh (ZPT) seperti dari bahan alami untuk stumulasi akar dan perbaikan komponen media tanam. Penelitian ini bertujuan untuk mengetahui konsentrasi urine kambing dan komponen media tanam yang tepat untuk pertumbuhan stek jambu air Deli Hijau (Syzygium aqueum Merr). Penelitian dilaksanakan di Kampung Cihonje Desa Karanganyar Kecamatan Mangkubumi Kabupaten Tasikmalaya pada bulan Maret sampai Mei 2021. Metode yang digunakan adalah metode eksperimental menggunakan Rancangan Acak Kelompok (RAK) pola faktorial $4 \times 2$ diulang sebanyak empat kali. Faktor pertama adalah konsentrasi urine kambing dengan empat taraf, yaitu $\mathrm{k}_{0}=$ tanpa konsentrasi urine kambing atau menggunakan air (kontrol), $\mathrm{k}_{1}=$ konsentrasi urine kambing $10 \%, \mathrm{k}_{2}=$ konsentrasi urine kambing $15 \%$, dan $\mathrm{k}_{3}=$ konsentrasi urine kambing $20 \%$. Faktor kedua adalah media tanam terdiri dari dua taraf, yaitu $\mathrm{m}_{1}$ $=$ tanah + pasir dan $m_{2}=$ tanah + pasir + arang sekam. Data dianalisis menggunakan sidik ragam dengan uji F dan dilanjutkan dengan Uji Jarak Berganda Duncan dengan taraf nyata 5\%. Hasil penelitian menunjukkan tidak terdapat interaksi antara perlakuan konsentrasi urine kambing dan media tanam terhadap pertumbuhan stek. Pemberian konsentrasi urine kambing $15 \%$ secara mandiri memberikan pengaruh terbaik terhadap rata-rata jumlah tunas pada $42 \mathrm{hst}, 56 \mathrm{hst}$, jumlah daun pada 56 hst dan panjang akar pada 56 hst.
\end{abstract}

Kata Kunci : Media Tanam, Stek Batang, Urine Kambing, Jambu Air

\begin{abstract}
The problem that is often faced in the propagation of rose water apple cv. Green Deli through stem cuttings is that the roots are difficult to grow. One of the efforts that can be done is by giving plant growth regulators (PGRs) such as from natural ingredients for root stimulation and improvement of planting media components. The research was aimed to determine the appropriate concentration of goat urine and the component of growing media for growth of rose water apple (Syzygium aqueum Merr.) cv. Green Deli. This research was done in Jl. Cihonje, Tasikmalaya District from March until May 2021. The method used is an experimental method using a
\end{abstract}


Randomized Block Design in factorial pattern, consisted of two factors. The first factor is the goat urine concentration, consisted of four goat urine concentrations, i.e $0 \%\left(\mathrm{k}_{0}\right), 10 \%\left(\mathrm{k}_{1}\right), 15 \%\left(\mathrm{k}_{2}\right)$, $20 \%\left(\mathrm{k}_{3}\right)$. The second factor is planting medium, consisted of two planting mediums i.e soil + sand $\left(\mathrm{m}_{1}\right)$ and soil + sand + rice husk charcoal $\left(\mathrm{m}_{2}\right)$. Each treatment is replicated four times, therefore, there were 32 experimental units. The data collected were analyzed using analysis of variance with F test and continued by Duncan's Multiple Range Test with 5\% of critical value. The result showed that there were no interaction between goat urine concentration and planting medium to all parameters of stem cuttings growth. Goat urine concentration of $15 \%$ gave best effect to number of shoots at 42 days and 56 days after planting (DAP), number of leaves at 56 $\mathrm{DAP}$, and length of roots at $56 \mathrm{DAP}$.

Keywords : Goat Urine, Planting Medium, Rose Water Apple, Stem Cuttings

\section{PENDAHULUAN}

Tanaman jambu air merupakan salah satu keanekaragaman tanaman yang dimiliki Indonesia yang memberikan manfaat dalam dunia kesehatan. Tanaman jambu air dapat digunakan untuk obat alami yang bermanfaat dalam menyembuhkan atau memperbaiki kondisi kesehatan masyarakat (Fauzi, 2018).

Peluang pasar komoditas jambu air Deli Hijau masih terbuka lebar dalam bidang hortikultura, namun dalam pengembangan tanaman jambu air Deli Hijau petani masih banyak mengalami hambatan terutama dalam penyediaan bibit yang berkualitas, pengetahuan, teknologi serta biaya permodalan yang masih kurang (Haryanto, 2000).

Dalam budidaya tanaman jambu air Deli Hijau, petani sangat membutuhkan keterampilan dan pengetahuan terhadap kondisi lingkungan tempat tumbuh tanaman, dalam hal ini berkaitan dengan ketersediaan air, kesesuaian tanah, ketersediaan unsur hara dan sebagainya. Tanaman ini pada umumnya menyukai media tanam yang subur, banyak mengandung bahan organik, sistem aerase dan drainase didalam tanah yang baik serta gembur (Hartawan, 2008).

Dalam memenuhi kebutuhan akan jambu air, perlu adanya peningkatan produksi buah jambu yang berkualitas. Dalam budidaya untuk dapat menghasilkan buah jambu air yang berkualitas diperlukan kualitas bibit yang baik, karena bibit yang sehat dan baik dapat meningkatkan produksi tanaman dan kaulitas buahnya. Bahan perbanyakan tanaman jambu air dengan stek dapat diperoleh dari bagian cabang tanaman, baik dari ujung cabang tersier maupun cabang sekunder. Dengan stek, dapat diperoleh bibit unggul dalam jumlah yang banyak dan dalam waktu yang singkat (Pradani, Rianto dan Susilawati, 2018).

Perbanyakan melalui stek batang memiliki permasalahan yaitu perakaran yang sulit tumbuh, sehingga diperlukan zat pengatur tumbuh (ZPT) untuk merangsang pertumbuhan akar. Pemberian zat pengatur tumbuh (ZPT) diperlukan untuk mendorong, merangsang, dan mempercepat pembentukan akar, serta meningkatkan mutu akar dan jumlah akar (Sinaga, Sitepu dan Meiriani, 2015).

Urine kambing merupakan pilihan bijak untuk mengurangi ketergantungan para petani dari penggunaan bahan sintetik atau anorganik. Penggunaan urine kambing akan menciptakan pertanian berkelanjutan yaitu limbah peternakan untuk pertanian dan sebaliknya limbah pertanian untuk peternakan. Urine kambing dapat digunakan untuk memacu pembelahan sel, pemanjangan sel hingga terjadi pembentukan akar, batang, daun, dahan, ranting, bunga dan buah (Rohaeni dan Aryanto, 2020). 
Penyediaan bibit yang berkualitas baik, sehat serta tumbuh lebih cepat dapat dilakukan melalui penyediaan bibit yang ditangkarkan terlebih dahulu dengan perlakuan khusus seperti pemilihan media yang tepat serta menjaga kesuburannya (Krisnaningsih, 2009).

Tanah sebagai media tempat tumbuh dan berkembang tanaman berfungsi menjadi tempat menyediakan mineral, unsur hara penting, air, dan udara. Pasir memiliki kapasitas mengikat air yang sangat rendah dan kandungan hara rendah (Aurum, 2005). Kelebihan dari media ini adalah kemampuan airase dan drainase yang baik, pasir mampu menyerap banyak air namun mudah juga untuk kering. Oleh karena itu, pasir akan lebih cocok jika dijadikan media campuran.

Sekam padi memiliki banyak manfaat, terutama dalam bidang pertanian. Salah satu cara untuk merubah sekam menjadi bahan yang lebih bermanfaat bagi usaha pertanian adalah arang sekam (Surdianto dkk, 2018).

Media tanam yang baik adalah media tanam yang mampu menyediakan air dan unsur hara dalam jumlah cukup bagi pertumbuhan tanaman. Hal ini dapat ditemukan pada tanah dengan tata udara dan air yang baik, mempunyai agregat yang mantap, kemampuan menahan air yang baik dan ruang untuk perakaran yang cukup (Gardner, Pearce dan Mitchell, 1991).

Berdasarkan latar belakang, diperlukan penelitian mengenai "Pengaruh Konsentrasi Urine Kambing dan Media Tanam terhadap Pertumbuhan Stek Batang Jambu Air Deli Hijau (Syzygium aqueum Merr.)" yang berguna untuk memanfaatkan urine kambing sebagai zat pengatur tumbuh pada tanaman jambu air dengan konsentrasi urine kambing dan media tanam yang berbeda. Diharapkan penelitian ini dapat mengoptimalkan pertumbuhan akar dan pertumbuhan tunas pada tanaman jambu air Deli Hijau (Syzyium aqueum Merr.).

\section{BAHAN DAN METODE}

\section{Waktu dan Tempat}

Penelitian ini dilaksanakan pada bulan Maret sampai dengan Mei 2021 bertempat di Kampung Cihonje Desa Karanganyar Kecamatan Mangkubumi Kabupaten Tasikmalaya Jawa Barat dengan ketinggian 375 mdpl.

\section{Alat dan Bahan}

Alat yang digunakan dalam penelitian adalah cangkul, meteran, penggaris, gelas ukur, timbangan, gunting stek, cutter, pisau, plang nama, thermo hygrometer, alat tulis, kamera, kalkulator, dan ember.

Bahan yang digunakan dalam penelitian ini adalah urine kambing, air, tanah, pasir, arang sekam, polybag, plastik, bambu, paranet, dan stek batang jambu air (jambu Deli Hijau) yang berasal dari Balai Penelitian Pengembangan Benih Hortikultura dan Aneka Tanaman di JL.Raya Jatinangor, Pasir Banteng, Kecamatan Jatinangor, Kabupaten Sumedang.

\section{Metode Penelitian}

Metode yang digunakan adalah metode eksperimen, dengan menggunakan Rancangan Acak Kelompok (RAK) pola faktorial dengan dua faktor dan diulang 4 kali.

Faktor pertama adalah konsentrasi urine kambing (K), yang terdiri dari 4 taraf, yaitu: $\mathrm{k}_{0}=$ kontrol (tanpa urine kambing)

$\mathrm{k}_{1}=10 \%$

$\mathrm{k}_{2}=15 \%$

$\mathrm{k}_{3}=20 \%$

Faktor kedua adalah media tanam (M), yang terdiri dari 2 taraf, yaitu:

$\mathrm{m}_{1}=\operatorname{tanah}+$ pasir $(1: 1)$

$\mathrm{m}_{2}=$ tanah + pasir + arang sekam $(1: 1: 1)$

\section{HASIL DAN PEMBAHASAN}

\section{Jumlah tunas}

Hasil analisis statistik menunjukkan konsentrasi urine kambing tidak 
berpengaruh nyata terhadap jumlah tunas pada umur $28 \mathrm{hst}$, tetapi berpengaruh nyata pada umur 42, 56 hst. Sebaliknya hasil analisis statistik pada media tanam tidak berpengaruh nyata pada setiap umur pengamatan (Tabel 1).

Tabel 1. Pengaruh konsentrasi urine kambing dan media tanam terhadap jumlah tunas (helai)

\begin{tabular}{|c|c|c|c|c|c|}
\hline \multirow[b]{2}{*}{ Media tanam (M) } & \multicolumn{4}{|c|}{ Konsentrasi urine kambing (K) } & \multirow[b]{2}{*}{ Rata-rata } \\
\hline & $\begin{array}{c}\mathrm{k}_{0} \\
(0 \%)\end{array}$ & $\begin{array}{c}\mathrm{k}_{1} \\
(10 \%)\end{array}$ & $\begin{array}{c}\mathrm{k}_{2} \\
(15 \%)\end{array}$ & $\begin{array}{c}\mathrm{k}_{3} \\
(20 \%) \\
\end{array}$ & \\
\hline \multicolumn{6}{|l|}{ Umur $28 \mathrm{hst}$} \\
\hline $\mathrm{m}_{1}($ tanah+pasir $)$ & 4,00 & 4,65 & 5,60 & 4,18 & $4,61 \mathrm{a}$ \\
\hline $\mathrm{m}_{2}($ tanah+pasir+arang sekam $)$ & 3,54 & 4,51 & 4,49 & 4,23 & $4,19 \mathrm{a}$ \\
\hline \multirow[t]{2}{*}{ Rata-rata } & 3,77 & 4,58 & 5,05 & 4,21 & \\
\hline & A & A & A & A & \\
\hline \multicolumn{6}{|l|}{ Umur 42 hst } \\
\hline $\mathrm{m}_{1}($ tanah+pasir $)$ & 6,10 & 7,00 & 7,80 & 6,50 & $6,85 \mathrm{a}$ \\
\hline $\mathrm{m}_{2}(\operatorname{tanah}+$ pasir+arang sekam $)$ & 5,76 & 7,28 & 7,18 & 5,88 & $6,53 \mathrm{a}$ \\
\hline \multirow[t]{2}{*}{ Rata-rata } & 5,93 & 7,14 & 7,49 & 6,19 & \\
\hline & A & $\mathrm{BC}$ & $\mathrm{C}$ & $\mathrm{AB}$ & \\
\hline \multicolumn{6}{|l|}{ Umur 56 hst } \\
\hline $\mathrm{m}_{1}($ tanah+pasir $)$ & 6,28 & 7,18 & 8,27 & 6,93 & $7,17 \mathrm{a}$ \\
\hline $\mathrm{m}_{2}(\operatorname{tanah}+$ pasir+arang sekam $)$ & 5,99 & 7,65 & 7,76 & 6,83 & $7,06 \mathrm{a}$ \\
\hline Rata-rata & 6,14 & 7,42 & 8,02 & 6,88 & \\
\hline & $\mathrm{A}$ & $\mathrm{BC}$ & $\mathrm{C}$ & $\mathrm{AB}$ & \\
\hline
\end{tabular}

Keterangan: Angka rata-rata yang diikuti oleh huruf besar yang sama pada baris dan huruf kecil yang sama pada kolom setiap umur pengamatan berbeda tidak nyata menurut Uji Jarak Berganda Duncan pada taraf nyata $5 \%$.

Tabel 1 menunjukkan perlakuan konsentrasi urine kambing 0\% sampai $20 \%$ tidak berpengaruh nyata terhadap jumlah tunas pada umur 28 hst. Hal ini diduga karena pada umur 28 hst tanaman masih pada kondisi awal pertumbuhan belum mampu menerima pengaruh perlakuan konsentrasi urine kambing atau masih menggunakan cadangan makanan pada stek yang digunakan sebagai sumber energi bagi pertumbuhan tunas. Hal ini sesuai dengan pernyataan Wudianto (2003) bahwa pada awal pertumbuhan stek, cadangan makanan yang dikandung dalam bahan stek yaitu karbohidrat dan nitrogen sangat mempengaruhi perkembangan tunas stek.
Perlakuan konsentrasi urine kambing berpengaruh nyata terhadap jumlah tunas pada umur 42, 56 hst, perlakuan konsentrasi $15 \%$ merupakan dosis yang tepat yang digunakan untuk memacu pertumbuhan tunas, sedangkan pada konsentrasi 20\% jumlah kadar auksin terlampau tinggi sehingga menghambat munculnya tunas. Diketahui urine kambing mampu menyediakan unsur hara makro $(\mathrm{N}, \mathrm{P}, \mathrm{K}, \mathrm{Ca}$, $\mathrm{Mg}$ ) dan mikro (Fe, $\mathrm{Cu}, \mathrm{Zn}, \mathrm{Mn}, \mathrm{Mo}, \mathrm{B}, \mathrm{Na}$, $\mathrm{Cl})$ serta mengandung zat pengatur tumbuh (ZPT) yang dibutuhkan tanaman (Abdullah $\mathrm{dkk}, 2011)$. Urine kambing mengandung $\mathrm{N}$ $1,50 \%$, P $0,13 \%$ dan $\mathrm{K} 1,80 \%$ serta mengandung hormon IAA $356 \mathrm{mg} / \mathrm{L}$ dan GA $938 \mathrm{mg} / \mathrm{L}$ (Saleh, 2004). 
Perlakuan konsentrasi urine kambing $20 \%$ menghasilkan rata-rata jumlah tunas yang lebih sedikit daripada perlakuan konsentrasi urine kambing 15\%. Pemberian hormon dengan konsentrasi yang tinggi belum tentu mampu meningkatkan pertumbuhan tanaman tetapi dapat juga menyebabkan keracunan pada tanaman. Hal ini sesuai dengan pernyataan Kusuma (2003) yang menyatakan bahwa dalam mengaplikasikan hormon perlu diperhatikan ketepatan dosis, karena jika dosis terlampau tinggi bukannya memacu pertumbuhan tanaman tetapi malah menghambat pertumbuhan tanaman dan menyebabkan keracunan pada seluruh jaringan tanaman.

Media tanam tidak berpengaruh nyata pada panjang tunas umur 28, 42 dan 56 hari setelah tanam. Penambahan arang sekam tidak dapat menambah jumlah tunas yang tumbuh. Hal ini diduga karena kandungan hara didalam arang sekam rendah dan umur stek masih relatif muda atau masih dipengaruhi oleh cadangan makanan pada bahan stek. Kandungan beberapa unsur hara makro didalam arang sekam tersebut adalah Nitrogen (N) 0,18\%, Fosfor (P) 0,08\%, Kalium (K) 0,3\%, Kalsium (Ca) 0,14\% serta unsur hara mikro Magnesium $(\mathrm{Mg})$ 0,5\%. Selain itu juga mengandung unsur lain seperti $\mathrm{Fe}, \mathrm{K}, \mathrm{Mg}, \mathrm{Ca}, \mathrm{Mn}, \mathrm{Mo}, \mathrm{B}$, dan $\mathrm{Cu}$ dalam jumlah yang kecil (Djafar, Musa dan Jamin 2012).

\section{Panjang tunas}

Dari hasil analisis statistik menunjukkan konsentrasi urine kambing dan media tanam tidak berpengaruh nyata pada setiap umur pengamatan (Tabel 2).

Tabel 2. Pengaruh konsentrasi urine kambing dan media tanam terhadap panjang tunas $(\mathrm{cm})$

\begin{tabular}{|c|c|c|c|c|c|}
\hline \multirow[b]{2}{*}{ Media tanam } & \multicolumn{4}{|c|}{ Konsentrasi urine kambing } & \multirow[t]{2}{*}{ Rata-rata } \\
\hline & $\begin{array}{c}\mathrm{k}_{0} \\
(0 \%)\end{array}$ & $\begin{array}{c}\mathrm{k}_{1} \\
(10 \%)\end{array}$ & $\begin{array}{c}\mathrm{k}_{2} \\
(15 \%)\end{array}$ & $\begin{array}{c}\mathrm{k}_{3} \\
(20 \%)\end{array}$ & \\
\hline \multirow{4}{*}{$\begin{array}{l}\text { Umur } 28 \text { hst } \\
\mathrm{m}_{1}(\text { tanah+pasir }) \\
\mathrm{m}_{2} \text { (tanah+pasir+arang sekam) } \\
\text { Rata-rata }\end{array}$} & 2,30 & 2,53 & 2,68 & 2,58 & $2,52 \mathrm{a}$ \\
\hline & 2,37 & 2,35 & 2,23 & 2,30 & $2,31 \mathrm{a}$ \\
\hline & 2,33 & 2,44 & 2,45 & 2,44 & \\
\hline & $\mathrm{A}$ & $\mathrm{A}$ & $\mathrm{A}$ & $\mathrm{A}$ & \\
\hline \multirow{5}{*}{$\begin{array}{l}\text { Umur } 42 \text { hst } \\
\mathrm{m}_{1}(\text { tanah+pasir }) \\
\mathrm{m}_{2}(\text { tanah+pasir+arang sekam }) \\
\text { Rata-rata }\end{array}$} & & & & & \\
\hline & 2,43 & 2,70 & 2,98 & 2,65 & $2,69 \mathrm{a}$ \\
\hline & 2,55 & 2,53 & 2,60 & 2,48 & $2,54 \mathrm{a}$ \\
\hline & 2,49 & 2,61 & 2,79 & 2,56 & \\
\hline & $\mathrm{A}$ & $\mathrm{A}$ & $\mathrm{A}$ & $\mathrm{A}$ & \\
\hline \multirow{2}{*}{$\begin{array}{l}\text { Umur } 56 \text { hst } \\
\mathrm{m}_{1}(\text { tanah+pasir }) \\
\mathrm{m}_{2}(\text { tanah+pasir+arang sekam })\end{array}$} & 2,58 & 2,83 & 3,18 & 2,80 & $2,84 \mathrm{a}$ \\
\hline & 2,73 & 2,68 & 2,75 & 2,58 & $2,68 \mathrm{a}$ \\
\hline \multirow[t]{2}{*}{ Rata-rata } & 2,65 & 2,75 & 2,96 & 2,69 & \\
\hline & $\mathrm{A}$ & $\mathrm{A}$ & $\mathrm{A}$ & $\mathrm{A}$ & \\
\hline
\end{tabular}

Keterangan: Angka rata-rata yang diikuti oleh huruf besar yang sama pada baris dan huruf kecil yang sama pada kolom setiap umur pengamatan berbeda tidak nyata menurut Uji Jarak Berganda Duncan pada taraf nyata $5 \%$. 
Perlakuan pada konsentrasi urine kambing 0\% sampai $20 \%$ tidak berpengaruh terhadap panjang tunas. Hal tersebut diduga karena kandungan hara didalam urine kambing tidak mencukupi kebutuhan hara khususnya Nitrogen untuk pertumbuhan stek jambu air Deli Hijau, sehingga belum mampu menyebabkan terdorongnya atau terpacunya sel diujung batang untuk segera melakukan pembelahan dan pembesaran sel terutama di daerah meristem. Menurut Saleh (2004) bahwa komposisi unsur hara yang terkandung didalam urine kambing adalah air 92\%, Nitrogen $1,50 \%$, Fosfor 0,13\% dan Kalium $1,80 \%$.

Media tanam tidak berpengaruh terhadap panjang tunas. Hal ini diduga karena media tanam yang bertekstur pasir juga butirbutirnya berukuran besar, maka akan sulit menyerap (menahan) air dan unsur hara, sehingga media yang digunakan tidak mampu menahan atau menyimpan air yang cukup untuk kebutuhan stek jambu air Deli Hijau. Air dibutuhkan oleh tanaman untuk proses fotosintesis. Hal ini sejalan dengan pendapat Hayati dkk, (2012) bahwa media tanam harus memenuhi berbagai persyaratan antara lain dapat dijadikan tempat berpijak tanaman, mampu mengikat air dan unsur hara, mempunyai aerasi dan drainase yang baik, mampu mempertahankan kelembaban di sekitar akar tanaman, steril dan memiliki porositas yang baik.

Selain itu dengan penambahan arang sekam juga tidak dapat meningkatkan hasil yang maksimal. Hal ini sesuai dengan pendapat Riskiyah (2014) arang sekam memiliki kemampuan menyerap air yang rendah. Salah satu faktor yang mempengaruhi pertumbuhan stek batang jambu air Deli Hijau adalah terpenuhinya kebutuhan air bagi tanaman, karena air merupakan bahan terbesar penyusun jaringan tanaman. Air merupakan bahan yang sangat penting bagi tanaman untuk melakukan fotosintesis dan menghasilkan fotosintat yang kemudian disalurkan ke seluruh bagian tanaman.

\section{Jumlah daun}

Hasil analisis statistik menunjukkan konsentrasi urine kambing berpengaruh nyata terhadap jumlah daun, sedangkan hasil analisis statistik pada media tanam secara mandiri tidak berpengaruh nyata terhadap jumlah daun (Tabel 3).

Tabel 3. Pengaruh konsentrasi urine kambing dan media tanam terhadap jumlah daun (helai) pada umur 56 hst.

\begin{tabular}{|c|c|c|c|c|c|}
\hline \multirow[b]{2}{*}{ Media tanam } & \multicolumn{4}{|c|}{ Konsentrasi urine kambing } & \multirow[t]{2}{*}{ Rata-rata } \\
\hline & $\begin{array}{c}\mathrm{k}_{0} \\
(0 \%)\end{array}$ & $\begin{array}{c}\mathrm{k}_{1} \\
(10 \%)\end{array}$ & $\begin{array}{c}\mathrm{k}_{2} \\
(15 \%)\end{array}$ & $\begin{array}{c}\mathrm{k}_{3} \\
(20 \%)\end{array}$ & \\
\hline $\mathrm{m}_{1}(\tan a h+$ pasir $)$ & 10,58 & 12,23 & 14,63 & 12,48 & $12,48 \mathrm{a}$ \\
\hline $\mathrm{m}_{2}($ tanah+pasir+arang sekam $)$ & 10,46 & 12,58 & 13,54 & 12,18 & $12,19 \mathrm{a}$ \\
\hline Rata-rata & $\begin{array}{c}10,52 \\
\mathrm{~A}\end{array}$ & $\begin{array}{c}12,41 \\
\mathrm{AB}\end{array}$ & $\begin{array}{c}14,09 \\
\text { B }\end{array}$ & $\begin{array}{c}12,33 \\
\mathrm{AB}\end{array}$ & \\
\hline
\end{tabular}

Keterangan: Angka rata-rata yang diikuti oleh huruf besar yang sama pada baris dan huruf kecil yang sama pada kolom berbeda tidak nyata menurut Uji Jarak Berganda Duncan pada taraf nyata 5\%.

Perlakuan konsentrasi urine kambing berpengaruh nyata terhadap jumlah daun pada umur 56 hst, perlakuan konsentrasi 15\% menghasilkan jumlah daun terbanyak meskipun tidak berpengaruh nyata dengan konsentrasi $10 \%$ dan 20\%. Hal ini diduga karena unsur hara Nitrogen berperan dalam proses pertumbuhan, sintesis asam amino dan protein, juga mampu mendorong pertumbuhan tanaman secara keseluruhan, 
khususnya batang, cabang dan daun. Unsur hara Kalium juga berperan sebagai aktivasi berbagai enzim, percepatan pertumbuhan dan perkembangan jaringan meristem. Disamping itu juga peningkatan jumlah daun merupakan salah satu bentuk pertumbuhan yang merupakan hasil dari aktivitas pembelahan dan pemanjangan sel. Pemanjangan dan pembelahan sel ini salah satunya dipengaruhi oleh adanya peran dari hormon giberelin yang terdapat dalam urine kambing sehingga hormon tersebut bekerja mengatur pertumbuhan daun (Lestari, 2008).

Media tanam tidak berpengaruh nyata terhadap parameter jumlah daun. Hal ini diduga karena pori-pori media yang besar masih didapatkan pada media tanah + pasir maupun tanah + pasir + arang sekam. Pori-pori tanah merupakan bagian yang tidak terisi bahan padat tanah (terisi oleh udara atau air). Pori-pori tanah ini dapat dibedakan menjadi pori-pori kasar dan pori-pori halus. Tanahtanah pasir mempunyai pori-pori kasar lebih banyak daripada tanah liat. Tanah dengan banyak pori-pori kasar sulit menahan air sehingga tanaman mudah kekeringan (Sarwono, 2015).

\section{Panjang akar}

Hasil analisis statistik menunjukkan konsentrasi urine kambing berpengaruh nyata terhadap parameter panjang akar, sedangkan perlakuan pada media tanam tidak berpengaruh nyata terhadap parameter panjang akar (Tabel 4).

Tabel 4 menunjukkan konsentrasi urine kambing berpengaruh nyata terhadap panjang akar. Perlakuan konsentrasi 15\% menghasilkan panjang akar terbanyak dibandingkan dengan perlakuan yang lain. Hal ini diduga karena panjangnya akar pada stek diduga dipengaruhi oleh zat pengatur tumbuh yang terdapat pada urine kambing yang termasuk dalam kelompok auksin. Fungsi dari hormon auksin ini adalah membantu dalam proses mempercepat pertumbuhan, baik itu pertumbuhan akar maupun pertumbuhan batang, mempercepat perkecambahan dan membantu dalam proses pembelahan sel. Cara kerja hormon auksin ini adalah menginisiasi pemanjangan sel dan juga memacu protein tertentu yang ada di membran plasma sel tumbuhan untuk memompa ion $\mathrm{H}^{+}$ke dinding sel. Ion $\mathrm{H}^{+}$mengaktifkan enzim tertentu sehingga memutuskan beberapa ikatan silang hidrogen rantai molekul selulosa penyusun dinding sel. Sel tumbuhan kemudian memanjang akibat air yang masuk secara osmosis. Hal ini sesuai dengan pernyataan Simbolon (2008) bahwa asam indole asetat (IAA=Indole Acetic Acid) adalah auksin alami yang berfungsi untuk merangsang pembelahan sel, sintesis DNA kromosom, serta pertumbuhan aksis longitudinal tanaman, berguna untuk merangsang akar pada stek.

Tabel 4. Pengaruh konsentrasi urine kambing dan media tanam terhadap panjang akar $(\mathrm{cm})$ pada umur 56 hst.

\begin{tabular}{|c|c|c|c|c|c|}
\hline \multirow[b]{2}{*}{ Media tanam } & \multicolumn{4}{|c|}{ Konsentrasi urine kambing } & Rata-rata \\
\hline & $\begin{array}{c}\mathrm{k}_{0} \\
(0 \%)\end{array}$ & $\begin{array}{c}\mathrm{k}_{1} \\
(10 \%)\end{array}$ & $\begin{array}{c}\mathrm{k}_{2} \\
(15 \%)\end{array}$ & $\begin{array}{c}\mathrm{k}_{3} \\
(20 \%)\end{array}$ & \\
\hline $\mathrm{m}_{1}(\operatorname{tanah}+$ pasir $)$ & 3,75 & 4,23 & 5,18 & 3,95 & $4,28 \mathrm{a}$ \\
\hline $\mathrm{m}_{2}(\operatorname{tanah}+$ pasir+arang sekam $)$ & 3,50 & 3,85 & 4,48 & 3,70 & 3,88 a \\
\hline Rata-rata & $\begin{array}{c}3,63 \\
\mathrm{~A} \\
\end{array}$ & $\begin{array}{c}4,04 \\
\mathrm{~A}\end{array}$ & $\begin{array}{c}4,83 \\
\text { B } \\
\end{array}$ & $\begin{array}{c}3,83 \\
\mathrm{~A}\end{array}$ & \\
\hline
\end{tabular}

Keterangan: Angka rata-rata yang diikuti oleh huruf besar yang sama pada baris dan huruf kecil yang sama pada kolom berbeda tidak nyata menurut Uji Jarak Berganda Duncan pada taraf nyata 5\%. 
Media tanam tidak berpengaruh nyata terhadap parameter panjang akar. Hal ini diduga karena media yang digunakan tidak mampu menahan atau menyimpan air yang cukup dan kandungan unsur hara didalam media rendah sehingga kurang mencukupi kebutuhan unsur hara tanaman. Sejalan dengan pendapat Idris, Rahayu dan Firmansyah (2018) bahwa kandungan bahan organik dan c-organik yang rendah akan mempengaruhi penyerapan unsur hara dan metabolisme pada tanaman yang berakibat kurangnya nutrisi pada akar.

\section{Volume akar}

Hasil analisis statistik menunjukkan konsentrasi urine kambing dan media tanam tidak berpengaruh nyata terhadap parameter volume akar (Tabel 5).

Tabel 5. Pengaruh konsentrasi urine kambing dan media tanam terhadap volume akar (ml) pada umur 56 hst.

\begin{tabular}{lccccc}
\hline \multirow{2}{*}{ Media tanam } & \multicolumn{4}{c}{ Konsentrasi urine kambing } & Rata-rata \\
\cline { 2 - 6 } & $\mathrm{k}_{0}$ & $\mathrm{k}_{1}$ & $\mathrm{k}_{2}$ & $\mathrm{k}_{3}$ & \\
\hline $\mathrm{m}_{1}$ (tanah+pasir) & $0 \%)$ & $(10 \%)$ & $(15 \%)$ & $(20 \%)$ & \\
$\mathrm{m}_{2}$ (tanah+pasir+arang sekam) & 0,63 & 0,63 & 0,75 & 0,50 & $0,63 \mathrm{a}$ \\
Rata-rata & 0,63 & 0,63 & 0,75 & 0,63 & $0,66 \mathrm{a}$ \\
& 0,63 & 0,63 & 0,75 & 0,57 & \\
& $\mathrm{~A}$ & $\mathrm{~A}$ & $\mathrm{~A}$ & $\mathrm{~A}$ & \\
\hline
\end{tabular}

Keterangan: Angka rata-rata yang diikuti oleh huruf besar yang sama pada baris dan huruf kecil yang sama pada kolom berbeda tidak nyata menurut Uji Jarak Berganda Duncan pada taraf nyata 5\%.

Hasil analisis ragam menunjukkan perlakuan mandiri konsentrasi urine kambing tidak berpengaruh nyata terhadap volume akar tanaman jambu air Deli Hijau pada umur 56 hst. Hal ini diduga dipengaruhi oleh faktor dalam seperti umur bahan stek, cadangan makanan dan faktor lingkungan seperti suhu dan kelembaban. Menurut Karsono dan Siswandono (2005), pertumbuhan awal terbentuknya akar dimulai oleh adanya metabolisme cadangan nutrisi yang berupa karbohidrat yang menghasilkan energi yang selanjutnya mendorong pembentukan primordia akar menjadi akar.

Media tanam tidak berpengaruh nyata terhadap volume akar. Hal ini diduga media yang digunakan mempunyai pori-pori besar, daya mengikat air yang rendah dan Fosfor pada tanah percobaan rendah (hasil analisis tanah) sehingga media yang digunakan belum cukup untuk mendorong pertumbuhan akar pada tanaman jambu air Deli Hijau. Hal ini sejalan dengan pendapat Enkeshwer,
Tyagi dan Sumariya (2010) bahwa media tanam dikatakan subur jika memiliki kemampuan untuk menyediakan unsur hara dalam jumlah yang cukup dan berimbang.

\section{SIMPULAN}

Berdasarkan hasil penelitian dan pembahasan maka dapat dikemukakan kesimpulan sebagai berikut :

a. Tidak terjadi interaksi antara konsentrasi urine kambing dan media tanam terhadap pertumbuhan stek batang jambu air Deli Hijau terhadap semua parameter pengamatan.

b. Penggunaan konsentrasi urine kambing $15 \%$ memberikan pengaruh paling baik terhadap jumlah tunas umur 42, 56 hst, jumlah daun 56 hst dan panjang akar 56 hst pada stek batang jambu air Deli Hijau (Syzygium aqueum Merr.). 


\section{SARAN}

Dari percobaan yang telah dilakukan, maka dapat dikemukakan saran :

a. Diperlukan penelitian lebih lanjut mengenai penggunaan media tanam yang dikombinasikan dengan penambahan pupuk kandang.

b. Konsentrasi urine kambing $15 \%$ dapat direkomendasikan/ diaplikasikan kepada petani untuk meningkatkan pertumbuhan bibit stek batang jambu air Deli Hijau (Syzygium aqueum Merr.)

\section{DAFTAR PUSTAKA}

Abdullah, L., Budhie, D. D. S. \& Lubis, A. D. (2011). Pengaruh aplikasi urine kambing dan pupuk cair organik komersial terhadap beberapa parameter agronomi pada tanaman pakan Indigofera sp. Jurnal Pastura, 1 (1): 5-8.

Aurum, M. (2005). Pengaruh jenis media tanam dan pupuk kandang terhadap pertumbuhan stek sambang colok (Aerva sanguinolenta $L$ ). Program Studi Agronomi. Fakultas Pertanian. IPB. Bogor.

Djafar. F., Musa, N. dan Jamin, F.S. (2012). Kajian tentang pertumbuhan dan hasil tanaman sawi (Brassica juncea L.) berdasarkan media tanam tanah dan sekam dengan dosis yang berbeda. Program Studi Agroteknologi Fakultas Pertanian Universitas Sumatera Utara. Medan.

Enkeshwer, P. R., Tyagi, S. dan Sumariya, H.K. (2010). Experimental studies on the effects of certain growth regulators on seed germination of stevia rebaudiana bertoni, Biosciences Biotechnology Research Asia.

Fauzi, A.M. (2018). Pengaruh konsentrasi indole butyric acid terhadap pertumbuhan stek tiga varietas tanaman jambu air (Syzygium Aqueum Merr.). Program Studi Agroteknologi Fakultas Sains dan Teknologi Universitas Islam Negri Sunan Gunung Djati, Bandung.

Gardner. F. P., Pearce R. B. dan Mitchell. R. I. (1991). Fisiologi Tanaman Budidaya. Universitas Indonesia. Jakarta.

Hartawan, R. (2008). Variabilitas pertumbuhan bibit jambu air asal benih unggul dan liar. Jurnal Media Akademik 2 (1) : 34-43.

Haryanto, P. (2000). Jambu air, jenis, perbanyakan dan perawatan. Universitas Gadjah Mada Press. Yogyakarta. 240 hal.

Hayati. E, Sabaruddin dan Rahmawati. (2012). Pengaruh jumlah mata tunas dan komposisi media tanam terhadap pertumbuhan stek tanaman jarak pagar (Jatropha curcas L). Program Studi Agroteknologi Fakultas Pertanian Universitas Syiah Kuala, Banda Aceh.

Idris, E. Rahayu, dan Firmansyah. E. (2018). Pengaruh komposisi media tanam dan volume air siraman terhadap pertumbuhan bibit kelapa sawit (Elaeis guineensis Jacq). Jurusan Agroteknologi Fakultas Pertanian STIPER. Yogyakarta.

Karsono, D.H. dan Siswandono. (2005). Pengaruh nomor ruas stek dan dosis pupuk urea terhadap pertumbuhan dan hasil tanaman kumis kucing (Orthosiphon aristatus Miq). Jurnal Ilmu Pertanian. 12 (1): 56-64.

Krisnaningsih. (2009). Pengaruh jenis media tanam dan dosis nitrogen terhadap pertumbuhan bibit kakao (Theobroma cacao L.). Program Pascasarjana Udayana. Denpasar.

Kusuma, A. S. (2003). Pengaruh zat pengatur tumbuh rootone-f terhadap keberhasilan stek manglid (Manglietia glauca BI). Institut Pertanian Bogor. Bogor. 
Lestari. 2008. Pertumbuhan Klorofil dan Karetenoid serta Aktivitas Nitrat Reduktase Raufolvia Verticillata Lour pada Ketersediaan Air yang Berbeda. Skripsi. Agroteknologi UNS. Surakarta.

Pradani, I. Rianto, C, H. Susilawati. Y.E. (2018). Pengaruh macam bahan stek dan konsentrasi filtrat bawang merah (Allium cepa fa. Ascalonicum L) terhadap pertumbuhan bibit jambu air (Syzygium aqueum Merr.) varietas citra. Jurnal Ilmu Pertanian Tropika dan Subtropika. 4 (1): 24-28.

Riskiyah. (2014). Peran mikroba dalam pertanian organik jurusan hama dan penyakit tumbuhan. Fakultas Pertanian. Universitas Padjadjaran. Bandung.

Rohaeni, N., dan Aryanto. D. (2020). Uji daya tumbuh stek tanaman alpukat (Persea americana Mill) dengan pemberian zat pengatur tumbuh nabati urine kambing. Sekolah Tinggi Pertanian Kutai Timur. Kutai Timur.

Saleh, E. (2004). Dasar pengolahan ternak. Fakultas Pertanian Universitas Sumatera Utara. Medan.

Sarwono, H. (2015). Ilmu Tanah. Akademika Pressindo. Jakarta.

Simbolon. 2008. Pengaruh Zat Pengatur Tumbuh Akar dan Media Tanam terhadap Keberhasilan dan Pertumbuhan Stek Kamboja Jepang (Adenium abesum Forssk). Skripsi. Medan. Program Studi Agronomi, Universitas Sumatera Utara.

Sinaga, N. F., Sitepu, F. E. dan Meiriani. (2015). Pertumbuhan stek jambu air deli hijau (Syzygium aqueum Merr.) dengan bahan tanam dan konsentrasi IBA (Indole Butyric Acid) yang berbeda. Agroteknologi, 4 (1): 1872-1880.

Surdianto, Y., Sutrisna, Nana., Basuno. dan Solihin. (2018). Cara membuat arang sekam. Balai Pengkajian Teknologi Pertanian (BPTP) Jawa Barat: Bandung.
Wudianto. (2003). Membuat Stek, Cangkok, dan Okulasi. Penebar Swadaya: Jakarta. 